\title{
The Analysis of Efficiency And Investment Profitability of a Solar Water Heating System in a Multi-Family Building
}

\author{
Piotr Herbut ${ }^{1}$, Maciej Rzepczyński', Sabina Angrecka ${ }^{1 *}$ \\ 1 Department of Rural Building, University of Agriculture, al. Mickiewicza 24-28, 30-059 Krakow, Poland \\ * Corresponding author's e-mail: s.angrecka@ur.krakow.pl
}

\begin{abstract}
The study analyses the efficiency of a Solar Water Heating (SWH) system, potential financial savings and investment profitability. The analysis pertaining to the amount of energy generated by the collectors had been performed for the multi-family building within the span of two years. The efficiency of the system was determined by comparing the amount of energy from solar radiation incident on the surface of the collectors to the amount of energy generated by the collectors and fed to the existing Domestic Hot Water (DHW) system. The amount of energy generated by the collectors was approx. 70 GJ per year, at the efficiency of the SWH system equalling $36 \%$. The best time for the operation of the system was the period from April to September, during which the share of generated for DHW amounted to $78 \%$. It is reflected in the decreased consumption of gas by $6 \%$ throughout the year. Furthermore, based on the data about the efficiency and energy yield of the set of collectors, as well as data on insolation, the analysis was performed to determine the installation and operation costs and the depreciation period of the investigated SWH system.
\end{abstract}

Keywords: solar water heating system, DHW, solar radiation, gas, economy, multi-family building

\section{INTRODUCTION}

Until to the 1980 s, Poland had been selfsufficient in terms of energy supplies. Currently, Poland's own resources of fossil fuels allow us to meet approx. $70-80 \%$ of our demand for energy. Unfortunately, regardless of numerous state and EU support programmes, the share of energy self-sufficiency is not increasing quickly enough, whereas according to forecasts, until 2020 Poland will be capable of meeting less than $60 \%$ of residents' needs [Zimny 2002]. The demand for energy in Poland has been satisfied by coal, the mining of which has decreased from almost 180 million tonnes in 1979 to approx. 70 million tonnes per year at present. Primary energy from coal accommodates approx. $50-55 \%$ of the total demand for energy of our nation state [Government Centre for Strategic Studies, 2004; Kaliski et al. 2011]; however, its amount has been steadily decreasing, as the prices of fossil fuels grow and their resources become increasingly limited. It necessitates the search for the possibility of re- ducing the energy consumption not only in residential, but also agricultural buildings [Angrecka and Herbut 2016; Nawalany et al. 2010; Nawalany et al. 2014; Nawalany et al. 2017]. This forces the search for new energy sources and the need to reduce the emission of carbon dioxide produced in the combustion of fossil fuels [Travnícek et al. 2018; Bloch-Michalik and Gaworski 2017; Woch et al. 2015], which is regarded by many scientific communities as the main factor of the aggravating the greenhouse effect. Therefore, the rational use of available conventional sources of energy and the search for new, unconventional ones which are easy to obtain has become increasingly important [Bloch-Michalik and Gaworski 2016; Herbut et al. 2017].

In effect, it is necessary to increase the generation of energy from renewable sources. The share of primary energy from renewable sources in total primary energy for the previous years in Poland had risen from $6.1 \%$ in 2006 to $11.7 \%$ in 2012 [Kościółek and Ziółko 2015]. According to the data provided by the Central Statisti- 
cal Office (GUS), this share reached $13.1 \%$ in 2015. In compliance with EU recommendations, the generation of energy from renewable sources must be raised up to $15 \%$ until 2020 [Dec and Krupa 2014].

The percentage share of solar energy in renewable energy sources in Poland is low; in 2014 it was as low as $0.4 \%$. However, it is evident that there has been an increase by $0.2 \%$ in relation to 2011 [GUS 2015]. Solar collectors are growing in popularity; they allow the utilisation of solar energy for heating multi-family buildings, public utility buildings or swimming pools [Dec and Krupa 2014]. They are also one of the cheapest sources of renewable energy; therefore, in the light of future increases in energy prices, the number of potential investors who will decide to purchase solar collectors may increase even further.

The aim of the study was to determine the efficiency of the existing SWH (Solar Water Heating) system on the multi-family building and to calculate the potential financial savings for the investor and the profitability of the investment in the solar collectors.

\section{MATERIALS AND METHODS}

The study of the SWH system in the multifamily building, located in Cracow, was performed from January 2010 to December 2012. The energy generated by the SWH system within this period was read on a regular basis and the obtained data was compared with the results of solar radiation measurements for Cracow between 2006 and 2012 to determine the overall efficiency of the system. The analysis of savings on the gas consumption for DHW (Domestic Hot Water) system included the data concerning the bills paid by the housing association from 2006 to 2012 .

The efficiency of the SWH system was determined by comparing the amount of energy from solar radiation falling on the surface of the collectors to the amount of energy generated by the collectors and fed to the existing DHW system. Furthermore, based on the data on the efficiency and energy yield of the collectors, as well as data pertaining to insolation, the implementation costs of the investment were compared and the depreciation period of the system was determined.

\section{Location and technical data of the building}

The multi-family building in which the SWH system is installed was erected in 1997 and is located in Cracow at 26 Kwartowa street (E: $19^{\circ} 58^{\prime} 54$, N: $\left.50^{\circ} 05^{\prime} 36^{\prime \prime}\right)$. The building houses 64 dwellings, in which 125 people were living at the time of the study.

The building consists of six storeys, four of which are residential and two are non-residential: the garage and attic. The exterior walls of the building are multi-layered, made of MAX hollow bricks, thermally insulated with rock wool up to a thickness of $8 \mathrm{~cm}$, with a ventilation louvre and checker brick curtain wall. The technical data of the building is presented in Table 1 .

Until 2010, when the SWH system was installed, three Rapido gas boilers had been used with Girsch burners of $160 \mathrm{KW}$ each and four tanks of $500 \mathrm{~L}$ each.

\section{Technical data of the solar water heating system}

The SWH system was equipped with 17 vacuum tube collectors of IB-Sol 22-70 type and two collectors of IB-Sol 12-70 type. The total surface of the collectors in the system was $69.29 \mathrm{~m}^{2}$, of which $41.43 \mathrm{~m}^{2}$ was the absorber area. The technical parameters of the collectors are presented in Table 2.

The system was connected to the DHW system by adding three $1,000 \mathrm{~L}$ water tanks connected in a series to the existing tanks $(4 \times 500 \mathrm{~L})$ at the boiler station. The pump in the collector loop was activated when the temperature difference between the collector medium and buffer tank was higher than the value set in the differential

Table 1. Technical parameters of the investigated building

\begin{tabular}{|l|c|c|}
\hline \multicolumn{1}{|c|}{ Parameters } & Unit & Value \\
\hline Usable area & $\mathrm{m}^{2}$ & $5,398.25$ \\
\hline Total surface & $\mathrm{m}^{2}$ & $7,305.00$ \\
\hline Cubic volume & $\mathrm{m}^{3}$ & $15,900.30$ \\
\hline Building height & $\mathrm{m}$ & 18.67 \\
\hline Building length & $\mathrm{m}$ & 56.50 \\
\hline Building width & $\mathrm{m}$ & 32.00 \\
\hline Surface of heated rooms & $\mathrm{m}^{2}$ & $3,296.00$ \\
\hline Surface of unheated rooms & $\mathrm{m}^{2}$ & 2102.25 \\
\hline Facade surface & $\mathrm{m}^{2}$ & $2,975.00$ \\
\hline Surface of exterior woodwork & $\mathrm{m}^{2}$ & 437.00 \\
\hline Number of storeys & - & 6 \\
\hline
\end{tabular}


Table 2. Technical data of the solar collectors installed in the building [Insbud catalogue]

\begin{tabular}{|c|c|c|}
\hline Parameter/Model & $\begin{array}{l}\text { Ib-Sol } \\
12-70\end{array}$ & $\begin{array}{l}\text { Ib-Sol } \\
22-70\end{array}$ \\
\hline Piping length [m] & \multicolumn{2}{|c|}{1.7} \\
\hline Piping diameter [mm] & \multicolumn{2}{|c|}{70} \\
\hline Number of vacuum tubes [pcs.] & 12 & 22 \\
\hline Total weight $[\mathrm{kg}]$ & 46 & 84 \\
\hline Collector surface $\left[\mathrm{m}^{2}\right]$ & 2.09 & 3.83 \\
\hline Absorption area $\left[\mathrm{m}^{2}\right]$ & 1.25 & 2.29 \\
\hline Optical efficiency [\%] & 74.4 & 74.8 \\
\hline Linear loss coefficient $\left[\mathrm{W} \cdot \mathrm{m}^{-2} \cdot \mathrm{K}^{-1}\right]$ & 2.001 & 1.996 \\
\hline $\begin{array}{l}\text { Non-linear loss coefficient } \\
{\left[\mathrm{W} \cdot \mathrm{m}^{-2} \cdot \mathrm{K}^{-1}\right]}\end{array}$ & 0.0114 & 0.0112 \\
\hline Thermal yield* $[\mathrm{kW}]$ & 0.838 & 1.536 \\
\hline
\end{tabular}

* At $\mathrm{G}=1,000 \mathrm{~W} / \mathrm{m}^{2}$ and $\_\mathrm{T}=30^{\circ} \mathrm{K}$ for the entire collector

controller. It was working until the temperature difference fell by the specified value of hysteresis. The circulator pump in the examined system activated at the temperature difference of $8^{\circ} \mathrm{C}$ and deactivated at the hysteresis of $50 \%$, which was when the temperature difference dropped to $4^{\circ} \mathrm{C}$. The aim of such settings of the controller was to ensure profitability in terms of the energy production of the circuit activation and pump operation.

\section{Measuring equipment}

The heat meter installed in the SWH system enabled reading the amount of thermal energy generated by the system and fed to the DHW tanks, with the value expressed in gigajoules [GJ]. Owing to the heat meter, it was possible to read the mean values from the last 32 days preceding the measurement date, as well as read the volume of glycol flowing through the system.

The amount of solar radiation energy within the study period was determined on the basis of automatic results of hourly measurements at the measuring station in Cracow, registered with the Kipp \& Zonen CMP 6 pyranometer, with the measurement scope from 0 to $2,000 \mathrm{~W} \cdot \mathrm{m}^{-2}$.

\section{RESULTS AND DISCUSSION}

\section{Solar water heating system efficiency}

The amount of energy generated by collectors depends on the radiation reaching their surface. The land area of Poland is characterised by regional variation of solar energy resources. In the east and at the foreshore, the annual sum of solar energy per $1 \mathrm{~m}^{2}$ of a horizontal plane is $3,800 \mathrm{MJ}$, whereas in Warsaw - 3,480 MJ [Chochowski 2009]. In Cracow, as the research for 2010-2012 indicates, this parameter was $3,684 \mathrm{MJ} \mathrm{m}^{-2}$.

Nearly $80 \%$ of the annual sum of solar energy was recorded from April to September, with the maximum value in July. It is attributable to such factors as clear weather and high solar altitude. The lowest amount of solar energy was characteristic for December, when the Sun is lowest above the horizon. In effect, the efficiency of the collectors decreased more than tenfold in the winter months; this, coupled with lower temperatures, wind and greater heat losses, additionally lowered the system efficiency (Fig. 1).

Owing to the solar radiation measurements and the data obtained from the readings of energy generated by the collectors, it was possible to determine the efficiency of the SWH system under investigation, including the collector surface and losses due to the system length, southern exposure and inclination angle of the collectors [Wiśniewski 2008]. On these grounds, it has been observed that between 2010 and 2012 the share of energy yielded by the collectors and fed to the boiler station constituted approx. $36 \%$ of the solar

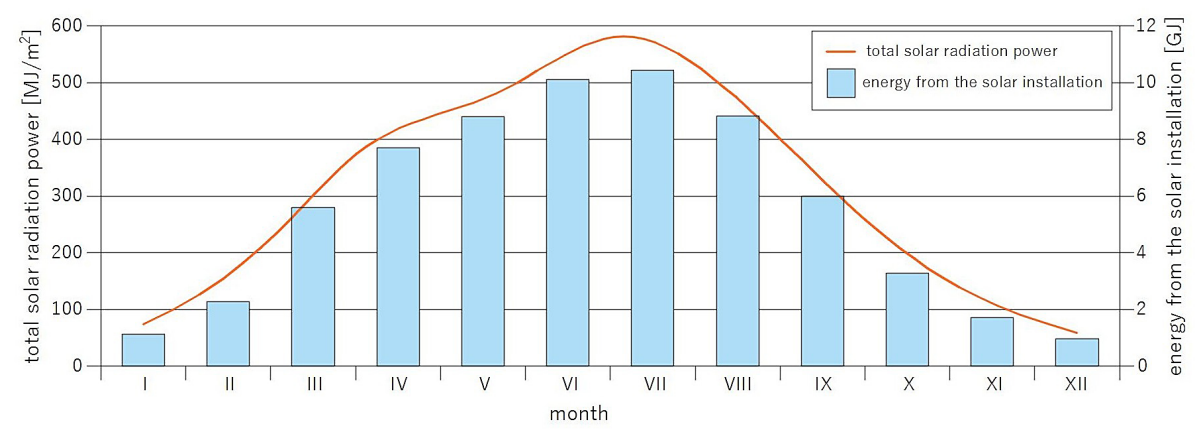

Figure 1. Correlation between the energy generated by the collectors and total solar radiation power in the investigated SWH system from 2010 to 2012 
radiation energy per $1 \mathrm{~m}^{2}$ of the absorber area. The efficiency of the heating system throughout the year was relatively stable. The reason was that the entire amount of generated energy was immediately used to satisfy the huge demand for the DHW system. The stable performance of the system was also influenced by remote monitoring that enabled the contractor to immediately react in the event of any problems during operation. Small fluctuations recorded during the operation of the system were caused by maintenance or layer of snow accumulated on the collectors in winter [Knaga 2011].

The calculated efficiency, in comparison to the one specified in the studies by Magiera and Głuszek [2008] and Radzajewska [2016], which is approx. $60 \%$, is far too low. Such a significant difference may be attributable to the method with which the solar thermal collectors were installed; the collectors examined for the studies under discussion were installed at the angle of $30^{\circ}$, whereas the optimal angles for the area of Poland fall within range of $40-50^{\circ}$. That would be compliant with the results given by Chochowski [2009], according to which, if vacuum tube collectors are installed on a roof at the angle of $40^{\circ}$, daily efficiencies reach approx. $40 \%$.

\section{Gas consumption}

The main purpose of the investor who decided to install the SWH system, aside from environmental protection, was the willingness to save money by decreasing the consumption of gas, a conventional energy carrier. Figure 2 presents the variations in the monthly consumption of gas for DHW by the boilers between 2006 and 2009 (without the collectors) and from 2010 to 2012 (with the collectors).

The average gas consumption throughout each calendar year between 2006 and 2009 (without the collectors) for heating $1 \mathrm{~m}^{3}$ of water was $12.4 \mathrm{~m}^{3}$. After the installation of collectors, it decreased by approx. $0.7 \mathrm{~m}^{3}$ to $11.7 \mathrm{~m}^{3}$. Figure 2 illustrates the decreased gas consumption after installing the SWH system, especially in the summer months, when the efficiency of the collectors was at the highest. As for the remaining months, the small amount of energy generated by the collectors did not change the gas consumption; any deviations on the chart are attributable to lower or higher temperatures of the pipeline water. The average consumption of gas used for heating $1 \mathrm{~m}^{3}$ DHW between 2006 and 2009 for the summer months, from May to September, was $8.7 \mathrm{~m}^{3}$, whereas from 2010 to 2012 it decreased by approx. $25 \%$, to $6.5 \mathrm{~m}^{3}$. The yearly consumption of gas went down by approx. $6 \%$, namely by the order of $2,000 \mathrm{~m}^{3}$.

\section{Economic analysis}

The membership of Poland in the European Union necessitated the adjustment of the energy policy to guidelines of the community and, therefore, utilisation of renewable energy sources and revision of legislation [Ignarska 2013]. Municipalities have taken advantage of the opportunity to use renewable energy sources not only to lower the energy costs for municipal institutions or individual end-users, but also for ecological reasons [Hernik 2008]. Especially considering that as the use of renewable energy sources in Poland is growing, the subsidies for private enterprises and

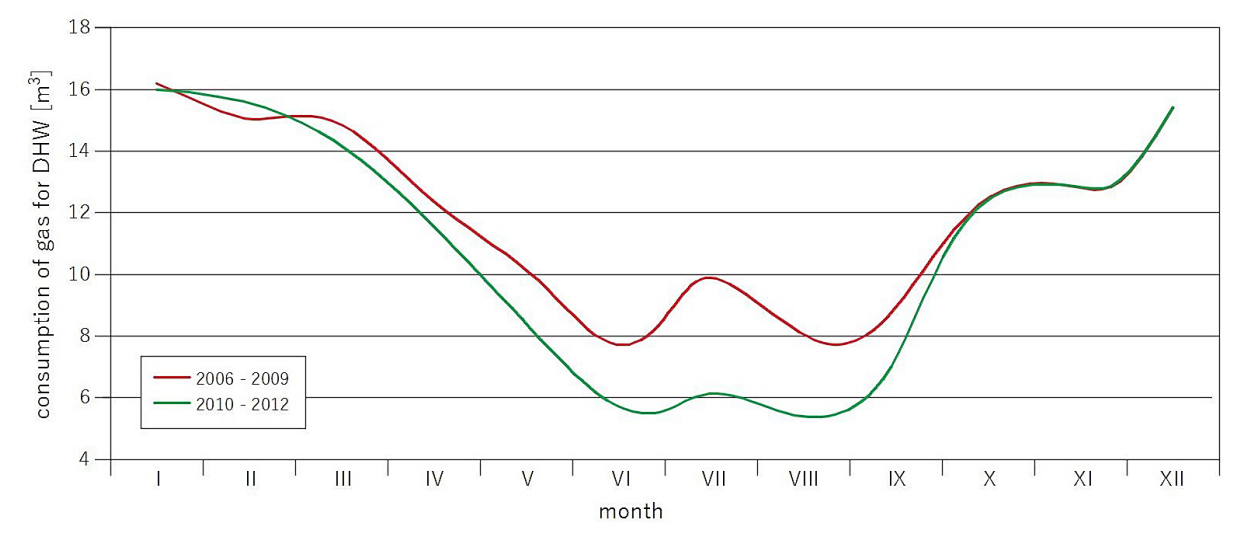

Figure 2. Gas consumption between 2006 and 2009 (without the collectors) and from 2010 to 2012 (with the collectors) 
local governments are provided, and the amount of the subsidies depends on the selected source and energy generated by that source. Furthermore, the purchase prices were established for the state to buy surpluses of the generated power [Skoczkowski et al. 2016].

In the presented study, the purchase cost of the system minus the amount of the subsidies which the investor was able to acquire from the Environmental Protection Department in Cracow was PLN 103,400. This amount should also be increased by annual running costs (maintenance, glycol change, electricity), which for the investigated system were PLN 352/year.

On the basis of the analysis of the total gas consumption in the building and the amount on invoices for gas paid by the housing association, the actual price of $1 \mathrm{~m}^{3}$ of gas was analysed from 2006, including the network fee and monthly fee (Fig. 3).

As the chart in Figure 3 shows, within the past six years, the mean price of $1 \mathrm{~m}^{3}$ of natural gas has increased by $65 \%$; it is also worth mentioning that earlier, between 1999 and 2006, the price of natural gas had soared by more than $100 \%$ [Wiśniewski 2008].

For the purpose of the analysis, it was assumed that $1 \mathrm{~m}^{3}$ of natural gas costs PLN 2.5 gross. Taking the actual gas prices into account and knowing the amount of energy generated by the collectors, an attempt was made to determine the actual time it took for the return on investment (ROI). After nearly a three-year analysis of the data acquired for the SWH system, it can be concluded that the mean annual amount of energy used for water heating was 66.9 GJ. The profit earned thanks to energy generated by the SWH system depended on the costs of energy from conventional sources (1 GJ of energy from gas cost PLN 73.14), which were replaced by energy from the solar thermal collectors and reduced by the annual running costs of the system; to be exact, this amounted to PLN 4,541.07/year.

Adopting the constant price of gas on the order of PLN 2.5 for $1 \mathrm{~m}^{3}$ and the final purchase cost of the system, that is PLN 103,400, the ROI rate was estimated at 23 years. This means that at the assumed service life - in the order of 20-25 years - regardless of the subsidies, the investment is borderline profitable. Bearing in mind that solar collectors are a solution most frequently selected by individual households, their use is questionable. In the presented analysis, the subsidies were $28.5 \%$ of the total investments costs. The subsidies offered between 2010 and 2014 for the purchase and installation of solar thermal collectors were $45 \%$ of the costs at most, whereas the effective subsidy made only $37 \%$ [Report 2014]. Be that as it may, after taking into account prices of rising energy carriers by $8 \%$ and the running costs by $5 \%$ on a yearly basis, the actual ROI rate in the examined instance was 13.4 or 16.3 years, if the SWH system were not to be subsidised.

\section{CONCLUSIONS}

1. The best period for operating the system was the second and third quarter (April to September) which yielded $78 \%$ of total generated energy. The lowest energy yield was recorded in the fourth quarter $(8 \%)$.

2. As regards the examined system, the consumption of gas went down by $25 \%$ in the summer months,

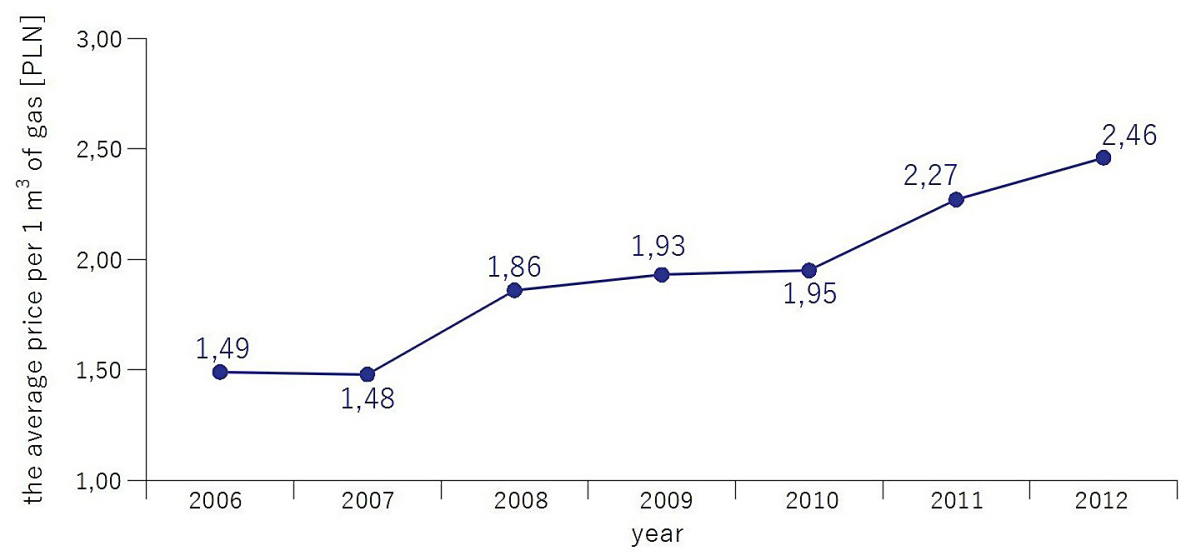

Figure 3. Price of $1 \mathrm{~m}^{3}$ of gas sustained by the housing association between 2006 and 2012 
whereas yearly - by $6 \%$. This corresponded with the consumption of $2,000 \mathrm{~m}^{3}$ of gas.

3. Owing to the solar thermal collectors, it was possible to generate and feed the Domestic Hot Water system with 66.9 GJ of thermal energy yearly.

4. At the gas price on the order of PLN 2.5 for $1 \mathrm{~m}^{3}$, the annual savings, including the running costs, were PLN 4,541.07.

5. The time for the return on investment in the system, taking into account the gas prices increasing by $8 \%$ and yearly running costs higher by $5 \%$, was 13.4 years.

\section{Acknowledgments}

This work was financed by the Ministry of Science and Higher Education of the Republic of Poland.

\section{REFERENCES}

1. Angrecka S., Herbut P. 2016. Impact of barn orientation on insolation and temperature of stalls surface. Annals of Animal Science, 16(3), 887-896.

2. Bloch-Michalik M., Gaworski M. 2016. Practical usage of additional heat from biogas plant. Agronomy Research, 14(S1), 1155-1160.

3. Bloch-Michalik M., Gaworski M. 2017. Agricultural vs forest biomass: production efficiency and future trends in Polish conditions. Agronomy Research, 15(2), 322-328.

4. Chochowski A. 2009. The state and prospects of research on the use of solar collectors in rural fruit harvests - current status and prospects (in Polish). Expertise. Warszawa.

5. Dec B., Krupa J. 2014. The use of renewable energy sources in the aspect of environmental protection (in Polish). Przegląd Naukowo-Metodyczny „Edukacja dla Bezpieczeństwa", 7(3), 722-757.

6. Główny Urząd Statystyczny. 2015. Energy from renewable sources in 2015 (in Polish). Warszawa.

7. Herbut P., Angrecka S., Herbut E., Nawalany G., Sokołowski P. 2017. Analysis of the heat profits from the helio active elements in prefabricated timbered building (in Polish). Infrastructure and ecology of rural areas, I/2, 409-418.

8. Hernik J. 2008. Need for considering cultural landscape virtues in rural commune management (in Polish). Zarządzanie Krajobrazem Kulturowym. Prace Komisji Krajobrazu Kulturowego Nr 10. Sosnowiec.

9. Ignarska M. 2013. Renewable energy in Poland (in Polish). Gospodarka, 1, 57-73.
10. Kaliski M., Jedynak Z., Janusz P., Szurlej A. 2011. Polish energy resources - a chance or a threat? (in Polish). Wiertnictwo, Nafta, Gaz, 28(3), 543-554.

11. Katalog Insbud. Vacuum tube collector Heat-pipe type (in Polish).

12. Knaga J. 2011. Analysis of the variability of solar energy conversion for a flat solar collector (in Polish). Inżynieria Rolnicza, 5(130), 107-115.

13. Kościółek M., Ziółko M. 2015. Share of renewable energy in energy balance Podkarpackie province (in Polish). Humanities and Social Sciences, XX. 22, 79-89.

14. Magiera J., Głuszek A. 2008. Possibilities of converting solar energy to thermal energy in Polish conditions (in Polish). Czysta energia - Czyste środowisko. Małopolsko-Podkarpacki Klaster Czystej Energii.

15. Nawalany G., Bieda W., Radoń J. 2010. Effect of floor heating and cooling of bedding on thermal conditions in the living area of broiler chickens. Archiv fur Geflugelkunde, 74(2), 98-101.

16. Nawalany G., Bieda W., Radoń J., Herbut P. 2014. Experimental study on development of thermal conditions in ground beneath a greenhouse. Energy and Buildings, 69, 103-111.

17. Nawalany G., Radoń J., Bieda W., Sokołowski P. 2017. Influence of Selected Factors on Heat Exchange with the Ground in a Greenhouse. Transactions of the ASABE. 60(2), 479-487.

18. Radzajewska P. 2016. Comparison of thermal characteristics of flat and tube solar collectors - an overview of selected technical solutions. Issues of energy resources and energy in the national economy (in Polish). Zakopane. ISBN 978-83-62922-67-3.

19. Raport. 2014. Solar collectors market in Poland and the Silesia province (in Polish). Park Naukowo-Technologiczny Euro-Centrum. Katowice.

20. Rządowe Centrum Studiów Strategicznych. 2004. Supplying the country with raw materials for fuels and energy in the long-term perspective (in Polish). Warszawa.

21. Skoczkowski T., Bielecki S., Baran Ł. 2016. (Renewable Energy Sources - Problems and Perspectives of Development in Poland (in Polish). Przegląd Elektrotechniczny, 3, 190-195.

22. Travnicek P., Kotek L., Junga P., Vitez T., Drapela K. 2018. Quantitative analyses of biogas plant accidents in Europe. Renewable Energy, 122, 89-97.

23. Wiśniewski G. 2008. Solar panels. Solar energy in housing, hotel industry and small industry (in Polish). Warszawa.

24. Woch F., Hernik J., Wyrozumska P., Czesak B. 2015. Residual Woody Waste Biomass as an Energy Source - Case Study. Pol. J. Environ. Stud, 24(1), 355-358.

25. Zimny J. 2002. We can be self-sufficient (in Polish). Nasz Dziennik, 14.01.2002. 